\title{
Comparative Review of the Magnitude of Transaction Costs in Construction Procurement Projects between Developed and Developing Countries
}

\author{
*1YAHAYA, ML; ${ }^{2}$ IBRAHIM, I; ${ }^{3}$ SANI, M \\ ${ }^{*}$ Department of Physical Planning and Development, Usmanu Danfodiyo University, Sokoto, Nigeria \\ ${ }^{2}$ Department of Building Technology, Federal Polytechnic Bauchi, Bauchi State, Nigeria \\ ${ }^{3}$ Department of Building, Faculty of Environmental Science Abubakar Tafawa Balewa University, Bauchi, Nigeria \\ *Corresponding Author Email: mohammedlawalyahaya@gmail.com; Tel: +2348033859343
}

\begin{abstract}
Contracting business in public sector within various counties has a transaction cost to incur. This paper reviews transaction costs magnitude of developed and developing countries using standard sampling and procedure by analyzing data from four (4) developed countries; United States of America, United Kingdom, Newzealand, and Czech Republic and two (2) developing countries in Africa; Ghana and Nigeria. According to the findings Newzealand have the highest TCs magnitude among all countries compared of about $16.5 \%$ averagely and with Czech Republic with $0.13 \%$ minimum that are incurred by stakeholders when bidding public sector construction projects. This is an important comparison and strengthens the assumption that there is a significant link between transaction costs incurred in bidding and public sector procurement, and that reducing such costs must be important for the contracting firms of various countries.
\end{abstract}

\section{DOI: https://dx.doi.org/10.4314/jasem.v24i3.21}

Copyright: Copyright $(C 2020$ Yahaya et al. This is an open access article distributed under the Creative Commons Attribution License (CCL), which permits unrestricted use, distribution, and reproduction in any medium, provided the original work is properly cited.

Dates: Received: 16 November 2019; Revised: 11 January 2020; Accepted: 22 February 2020

Keywords: Construction, Comparison, Magnitude, Procurement, Transaction Cost.

Transaction Costs magnitude in the construction procurement are a global challenge. Justifiably, it has drawn the attention of researchers from various countries of the world (Li, et al., 2013; Rajeh, 2014; Yahaya, et al., 2019a). Different research in this domain focuses on expenses incurred in the procurement system and its effects on economic system operation (Lv, et al., 2012; Hughes, 2016). Whittington (2008) observed that the transaction costs at the pre and post contract stages ranges from 0.4 to 8.8 percent (averagely 2.6 per cent) of the contract value. Nevertheless, transaction costs-related research findings from developing countries were disproportionate, which may be connected with the variables studies, institutional frameworks, type of procurement adopted, projects and contract policies in such countries (Lv et al., 2012; Li et al., 2013). Added to this, especially in the field of transaction, differing organisations, governments, cultural practices and ethical philosophies entail that research must be context-specific (Somers 2001; Spicer et al., 2004; Suen et al. 2007). Li et al., (2015) explored four factors that increase transaction costs in their study of determinant of transaction costs in construction projects in China. These include owner's roles, contractors' role, project management efficiency and characteristic of the transaction environment. The main goal of this paper is to compare the transaction cost magnitude of construction procurement projects of selected countries, with a view to identify differences which influence on quantity of these cost and the possible solutions offered in mitigating such costs in the various countries. Content analysis methodology was adopted in gathering data relating to magnitude of transaction costs in those countries. A simple descriptive analysis in the form of frequency bar chart was used in analyzing the data collected from various researches to draw a conclusion in the research. Commons in 1931 introduced the idea that transactions form the basis of economic thinking (Commons, 2001). However, it is generally believed that Roland Coase introduced the phrase "transaction cost" when used in formulating a theoretical framework for determining when specific economic tasks would be performed by both the firm and the market. However, the term did not appear in his works till the 1970s. Though Commons is not the initiator of the specific phrase, Coase discussed the "costs of using the price mechanism" in his 1937 paper, The Nature of the Firm, thus introducing the transaction costs concept (Jacobides, 2008). Successively, Jacobides (2008) explored pricing mechanisms and found that there are costs that are related to searching for relevant prices, negotiating, and making a contract (Coase 1992, Coase 1988, Coase 1960). However, it is Scitovsky (1940) who introduced the term 'transaction 
cost' into the economic vocabulary (Hardt, 2009). It is evident that Transaction Cost Economics long preexisted its introduction into research in economics. It has lived very long, but very shortly as a discipline of science. That account of TCE theory to have started with Oliver Williamson in the 1970s. It was in his 1979 paper (Transaction cost economics: the governance of contractual relations) that the term "Transaction Cost Economics" was first mentioned.

Definition of Transaction Costs: Review on transaction costs related literature has revealed that there is variation of standard definition of transaction costs within and across various research disciplines ( $\mathrm{Li}$ et al., 2015). While Williamson (2010) defines transaction costs to include the costs of drafting, negotiating and enforcing an agreement, and also the costs of governance and bonding to secure commitments, Li Arditi and Wang (2014) claim that transaction costs to include costs incurred by activities such as preparing a bid documents, estimating, drawing up a contract, administering the contract and dealing with any deviation from contract conditions are also important, which are part of transaction costs. And Joskow (1985) adds costs of acquiring and processing information, legal costs, organizational costs, and costs associated with inefficient pricing and production behavior. The concept of transaction cost is not universally accepted by all participants in the construction industry and has not received much recognition by modern practice (Li et al., 2015).

Transaction Costs Quantification: Determining the magnitude of transaction costs for construction projects has been a burning issue since it appears among researchers. However, the quantifying works face different challenges (Lv, Liu and Wang, 2012). First, as stated above, there is no consensus agreement on the definition of transaction costs among scholars (Benham and Benham 2001). So it is difficult to identify what transaction should be considered, what costs or expense should be regarded as transaction costs. Second, it's unseen that costs appear in the shape of indirect costs or value in the market. Because of different policy, attitudes, culture and customs, the behaviors in transaction lead to different transaction costs, they're too difficult to be calculated numerically (Liu and Shen, 2006). Thirdly, opportunity cost can't replace the transaction costs in the construction perspective. The activities conducted in transaction are just a little portion of numerous transaction operated in construction ( $\mathrm{Li}$ et al., 2015), and opportunity costs can just represent a part, but not all (Lv et al., 2012). It's also important for measuring transaction costs to analyze why the researcher adapts one but not others.
Transaction Cost in Developed Countries: The transaction costs measurement according to various literature in construction projects where basically analyze based on two phases. That is the pre-contract and post-contract transaction costs (Li et al., 2015; Rajeh, 2014; Dudkin and Valila, 2005). The precontract transaction costs are those cost incurred basically by contractor or client before signing of contract. Post-contract transaction costs include the costs incurred after the contract has been signed but before the entire transaction has been completed. It is based on this categorization that transaction costs magnitudes were determined in most developed countries studied. According to Whittington (2008) study of six different projects using traditional method of procurement in United State of America (USA). The studies revealed different magnitude of transaction costs, which range from $0.4 \%$ to $8.8 \%$ (Averagely $2.6 \%$ ) of the contract value. But it was found to be $0 \%$ to $5.7 \%$ for the design and build system of procurement (Averagely 2.2\%). These shows that the transaction costs at the pre-contract stage are higher with about $0.4 \%$ for traditional method, if compared with the design and build system (Dadzie, 2015). Similarly, Dudkin and Valila (2005) established that the transaction costs in the precontract phase of infrastructure projects using public private partnership (PPP) system is about $2-3 \%$ of the contract value on average. In the United Kingdom (UK) the transaction costs magnitude is range from $0 \%$ to $0.57 \%$ of the project costs were spent by contractors. Dufek (2013) determined the transaction costs of Czech Republic and it was found to be about $0.25 \%$ of the contract value. Based on literature survey it was found that the major factors influencing transaction costs in these countries are; costs of market survey, exploring financing, feasibility studies, bidding/negotiation, change orders, dispute resolution and incentive payments. Rajah (2014) study the impact of procurement system on transaction costs, with the aim of estimating transaction costs for different delivery system in-used in construction project in New Zealand. The result from the model validation shows about $18.5 \%$ and $14.5 \%$ of the annual salary of project managers were spent in traditional and design-build system by stakeholders during procurement processes.

Transaction Costs in Developing Countries: After exploring the transaction costs incurred in developed countries, which show a varying result within the countries. The next phase is to ascertain the transaction costs incurred in developing countries like Ghana, Gambia and Nigeria with a view to comparison and contrast the difference among countries. Dadzie (2015) estimate the impact of transaction costs of 
traditional and design-build system in Ghana. The study focused solely on factors such as information, administrative and bidding costs as the main drivers of transaction costs (TCs). Analysis of the result shows that contractors' spent from $10.90 \%$ to $1.87 \%$ of contract value as TCs for traditional and design-build system of procurement. Dadzie (2015) identified poor staffing, poor implementation, and ambiguity in the procurement clauses and political interference in the procurement processes are the major factors influencing TCs in the country. In Nigeria, similarly Yahaya et al., (2019b) in their work estimate the magnitude of transaction costs in bidding public sector projects. The authors found that about $8.21 \%$ of contract value was spent by contractors when bidding those projects. This according to their findings as a result of factors such as bidding/eligibility documents, contract administration and bidding expenses incurred by participant of the construction industry. Thus, their result has not state the minimum magnitude incurred and the type of procurement system in-used in arriving such percentage. However, there are similarities of the result among the developing countries as show from the literature explored. This brings an interesting findings and proof of previous studies that; "there were costs related to searching for relevant prices, negotiating and entering into contract" (Coase, 1960). On the other hand disconfirmed with neoclassical theory assumption that "trading value is determined exclusively on the basis of supply and demand variables" (Dietrich, 2012). Indicating that there is no any negotiating or searching costs because the price is already determined by the free market.

Comparison of Transaction costs among countries: In this section we summarized the various transaction costs incurred in developed and developing countries for traditional and design-build method of procurement. Most of the authors believe on the fact that there are transaction costs in relation to bidding public sector projects and it has an adverse impact on the contract value. According to some findings or result the transaction costs (TCs) at the pre-contract stage of traditional method is higher than in the designbuild method (Dadzie, 2015; Li et al., 2013; Whittingon, 2008). Figure 1 represents the graphical overview of the TCs magnitude in bar chart with their percentage $(\%)$ costs incurred for traditional and design-build method of procurement in relation to developed and developing countries analyzed. The chart indicated that Newzealand have the highest TCs magnitude in both traditional and design-build methods of $18.5 \%, 14.5 \%$ and $16.5 \%$ averagely in public sector procurement. But, Czech Republic has the lowest TCs magnitude within the developed countries of $0.25 \%$ and $0.13 \%$ as in Figure 1 .
Similarly, from Figure 1 bar chart it shows that Ghana have the highest TCs of $10.90 \%, 1.87 \%$ and $6.39 \%$ among the developing countries compared. Nigeria has $8.21 \%$ TCs for traditional procurement method, with $0 \%$ for the design-build method as indicated from the chart. This does not mean that there is no costs incurred to such method when used in public procurement, but rather researchers have not given much concentration due to the fact that about $80 \%$ to $95 \%$ of public sectors are carried out based on a default method (Traditional) in the country as stipulated by the public procurement Act 2007 (PPA 2007).

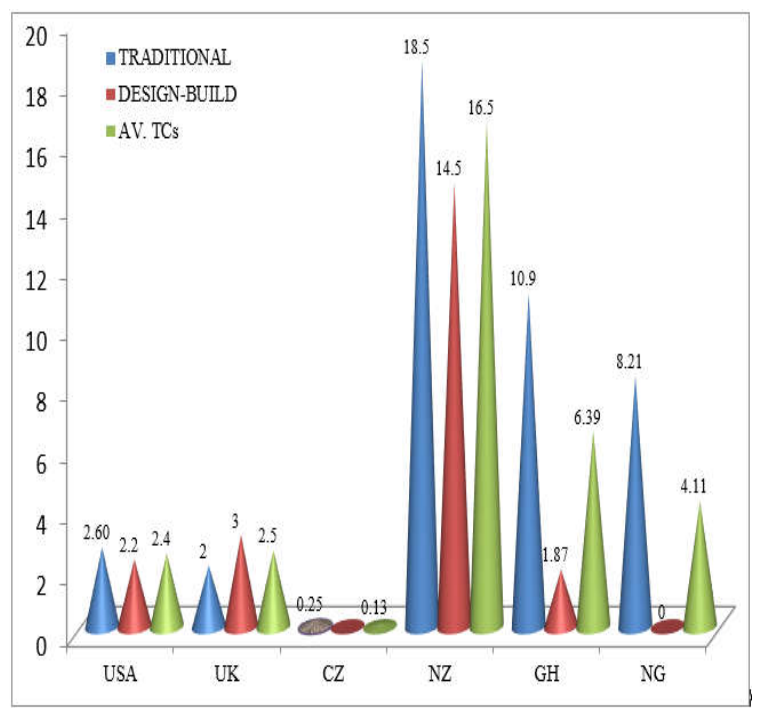

Fig 1: Transaction Costs Magnitude in Public Procurement Comparison between Countries

Factors/Variables influencing Transaction costs magnitudes among countries: In the process of procuring public construction projects, no matter whether it is in developing or developed countries, widespread factors have been discovered influencing the transaction costs. Such as interference from outside parties, monitoring, malpractice, noncompliance to the policies/Act, delayed in approvals, tender documentation and contract management (Hui et al., 2011; Noor et al., 2013). Table 1 below shows the various variable/drivers that influencing the transaction costs of different countries. Rajeh (2014) uses the classical definition of transaction costs and categorizes them into four main items to develop a model for TCs: searching/information cost, enforcement cost, project procurement costs, administration costs and professional costs. Sumpikova et al., (2019) attempt to estimate the Transaction Costs in the public procurement in Czech and Slovak and categorize transaction costs into four main categories: tender preparation costs, complaint costs, legal document costs and outsourcing costs. 
Table 1: Drivers of transaction costs magnitude in various

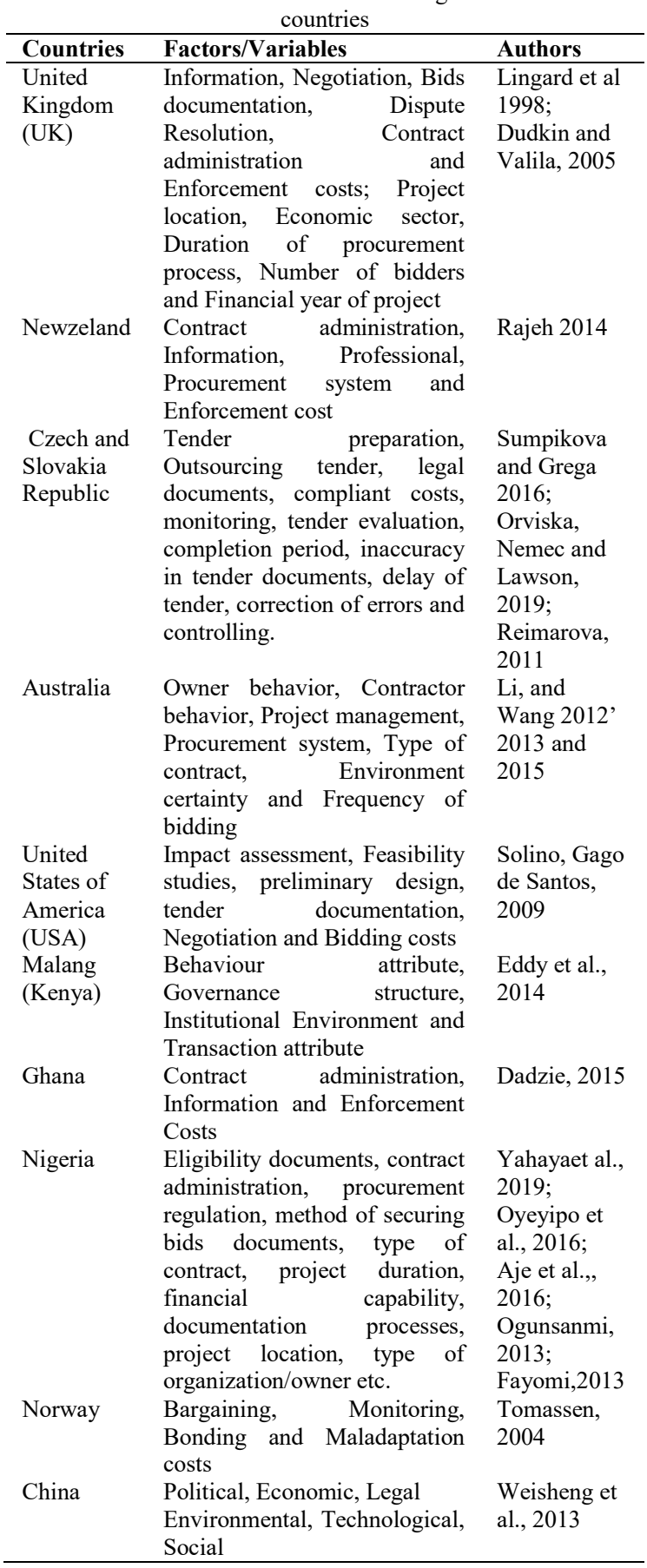

In Li, Arditi and Wang (2012 and 2013) study regarding transaction costs incurred by construction owners they develop the model based on project performance costs, magnitude of transaction costs, uncertainty of the environment, owners role in the transaction and contractors role in the transaction. Eddy, Gooi, and Chen (2014) assess the effects of Asymmetric information, Transaction cost to Corporate Governance, and Public organization performance in Malang. They develop a frame work that indicates how corporate governance and performance were affected due to influence of Asymmetric information and Transaction costs in some agencies in Malang.

In another study, Soliño and Santos (2009) try to distinguish, at every stage, between external costs (such as technical, legal and financial advice) and inhouse costs such as project preparation costs. These costs considered include the Environmental Impact Assessment, feasibility study, preliminary design, and bidding costs including tender documentation preparation and costs for negotiation. Their study is based on data collected from different infrastructure projects in the European Union (EU) that suggests a model to estimate the transaction cost of PPPs based on some variables (i.e.: type of project, capital cost of project, procurement duration, location, and number of bidders) as shown in Table 1. Fayomi (2013), in his studies "public procurement and due process policy in Nigeria" pointed out some factors contributing towards the high costs of transaction in the public procurement processes which includes; selective implementation by government in power, the use of non-professionals in procurement matters, unwillingness of official to comply with the Act, inadequate projects definitions by the procuring entities, shortfalls in professionalism in projects packaging and supervision; inadequate documents and documentation among others.

Discussion of Findings: The outcome of the review shows that transaction costs are mainly attributed due to those factors which increase the transaction in the construction project. In Czech Republic, Dufek (2013) measured private transaction costs of public procurement. The result of the study shows that market sector, contract prize and different types of the contracting authorities are the major factor influencing private transaction costs in Czech Republic, on averagely $0.25 \%$ of contract value. In the African countries, for instance Ghana, Dadzie (2015) compared the magnitude of transaction costs of traditional and Design-Build procurement system in public construction. Finds from the result reveals that politicization of the procurement process, poor staffing, poor implementation and ambiguity in the clause of the procurement Act are the core challenging factors of transaction costs increase. The effects of transaction cost magnitude are mainly in its discouragement of firms to participate in procurement tenders (less competition). Higher cost would lead to decrease in number of bidders. As shown in Kuhlman, Johnson (1983), Bajari (2001), Pavel (2010), there is an indirect dependency between final price and 
competition level. However, it is important to compare the transaction costs magnitude of construction procurement between developing and developed countries to explore their view and feeling in such area. Previous studies in the context of this research (notably Frajian 2010; Li et al., 2015; Dudkin \& Valila, 2005; Rajeh, 2014; Hughes, 2016) did not concentrate on this systematic comparison.

In summary, the result of the research shows that: Developed countries transaction costs are mainly attributed due to type of market, contract size, and type of organizations as the major influence of transaction costs in construction procurement. In developing countries factors such as: politics, poor staff, poor implementation and ambiguity in the procurement Laws sections as the major element of increasing transaction costs.

Conclusion: This study has contributed to knowledge, in the area of a lasting reform of the construction industry by understanding the difference as well as similarities of the main sources of transaction costs magnitude in contracting business. It affords the exposure of knowledge and information to network of professionals and contractors. Institutions like Quantity surveyors, contractors/suppliers Architect, Engineers and Bureau of public procurement shall benefit from this study. Systematic method of evaluation is enhanced with greater independence. It provides concise evidences that there are various factors affecting transaction costs in construction project procurement that are different between developed and developing countries.

\section{REFERENCES}

Aje, OI; Oladinrin, OT; Nwaole, CNA (2016). Factors influencing success rate of contractors in competitive bidding for construction works in South-East, Nigeria. J. of Const.in Dev. Count. 21(1): 19-34.

Benham, A; Benham, L (2001). The Costs of Exchange. Ronald Coase Institute Working Paper Series, Number 1, July.

Coase, RH (1937). The nature of the firm. Econ. 4(16), 386-405.

Coase, RH (1960). The problem of social cost Classic papers in natural resource economics (pp. 87-137): Springer.

Coase, RH (1988). The nature of the firm: Origin. J. of La. Econ. Org. 4(1), 3-17.

Coase, R H (1992). Contracts and the Activities of Firms. J. of La. Econ. 34(2), 451-452.
Dadzie, J (2015). Comparative estimation of the impact of transaction cost of traditional and design-build procurement system in public construction works. Unpublished Master of Science thesis in procurement management, department of building technology, college of art and built environment, Kwame Nkurumah University of Science and Technology, Kumasi, Ghana.

Dudkin, G; Välilä, T (2005). Transaction costs in publicprivate partnerships: a first look at the evidence. Economic and Financial Report, European Investment Bank.

Dufek, L (2013). Measuring private transaction costs of public procurement: Case of the Czech Republic. Acta Uni. Agri. Silv. Mendel. Brun. 61(2), 317-325.

Farajian, M (2010). Transaction cost estimation model for us infrastructure public private partnerships. MSc Thesis.University of Maryland, College Park, MD, USA.

Fayomi, IO (2013). Public procurement and due process policy in Nigeria: Thrust, prospects and challenges. Peak J. of Soc. Sci. Hum. 1(4), 39-45.

Grega, M; Orviska, M; Nemec, J; Lawson, C (2019). Factors Determining the Efficiency of Slovak Public Procurement. NISPAcee J. of Pub. Admin. and Pol. 12(1), 43-68.

Hughes, W (2016). The costs of bidding: Marketing work. Retrieved 10th February, 2018 www.marketingworktrading\&consultancyltd

Hui, WS; Othman, R; Omar, NH; Rahman, RA; Haron, NH (2011). Procurement issues in Malaysia. Inter. J. of pub. Sec. Manag. 24(6), 567-593

Jacobides, MG (2008). How capability differences, transaction costs, and learning curves interact to shape vertical scope. Org. Sci. 19(2), 306-326.

Jibrin, MS; Ejura, SB; Augustine, NI (2014). The public procurement reforms in Nigeria: Implementation and compliance challenges. J. of Asi. Bus. Stra. $4(11), 149-171$

Joskow, PL (1985). Vertical integration and long-term contracts: the case of coal-burning electric generating plants, J. of Law, Econ. Org. 1(1): 33-80

Li, H; Arditi, D; Wang, Z (2012). Factors that affect transaction costs in construction projects. J. of Const. Eng. and Manag. 139(1), 60-68.

Li, H; Arditi, D; Wang, Z (2015). Determinants of transaction costs in construction projects, J.of Civ. Eng. and Manag. 21(5), 548-558 
Lingard, H; Hughes, W; Chinyio, E (1998). The impact of contractor selection method on transaction costs: a review. J. of Const. Proc. 4(2), 89-102.

Liu, Z; Shen, J (2006). Measuring Transaction Costs: Theoretic Development and Application. Fin. and Tra. Econ. 10(1), 77-82

Lv, Z; Liu, Q; Wang, P (2012). Literatures review on transaction costs measurement advances. Asian Soc. Sci. 8(12), 127-132.

Muhammad, BA; Adamu, T; Ladi, BD (2015). Appraisal of construction project procurement policies in Nigeria. Ame. J. of Eng. Res. 4(3), 19-24.

Noor, MA; Khalfan, MM; Maqsood, T (2013). The role of procurement practices in effective implementation of infrastructure projects in Pakistan. Inter. J. of Manag. Proj. in Bus. 6(4), 802826.

Oyeyipo, O; Odusami, KT; Ojelabi, RA; Afolabi, AO (2016). Factors Affecting Contractors' Bidding Decisions for Construction Projects in Nigeria. J. of const. in develop. Count., 21(2), 21-35.

PPA (2007) Public Procurement Act 2007, Federal Republic of Nigeria

Rajeh, M (2014). Impact of procurement systems on transaction costs: A structural equation modeling methodology. Proceedings of the 4th New Zealand Built Environment Research Symposium (NZBERS). Auckland,New Zealand. Accessed 15 September 2018.

Reimarova, H (2011). Transaction costs in public procurement. Unpublished Post-graduate thesis. Prague, Charles University.

Soliño, AS; Gago de Santos, P (2009). Transaction costs in PPP transport infrastructure projects. Working paper. European Investment Bank. Retrieved August, 16, 2018.

Somers, M.J (2001). Ethical codes of conduct and organisational context: A study of the relationship between codes of conduct, employee behaviour and organizational values. J. of Bus. Ethics 30(2), 185195.

Spicer, A; Dunfee, TW; Bailey, WJ (2004). Does national context matter in ethical decision making? An empirical test of integrative social contracts theory. Acad. of Manag. J.47 (4), 610-620.

Suen, H; Cheung, SO; Mondejar, R (2007). Managing ethical behaviour in construction organisations in Asia: How do the teachings of Confucianism, Taoism and Buddhism and globalization influence ethics management? Inter. J. of Proj. Manag. 25(3), 257-265

Šumpíková, M; Bušina, F; Grega, M; Nemec, J; Orviská, M (2016). Transaction Costs in the Public Procurement: Selected Findings in Czech and Slovak Conditions. Paper presented at the Proceedings from International Scientific Conference International Days of Statistics and Economics. Prague: University of Economics in Prague.

Weisheng, L; MM Liu, A; Hongdi, W; Zhongbing, W (2013). Procurement innovation for public construction projects: A study of agent-construction system and public-private partnership in China. Eng. Const. and Arch. Manag. 20(6), 543-562.

Whittington, JM (2008). The transaction cost economics of highway project delivery: design-build contracting in three states: University of California, Berkeley.

Williamson, OE (2010). Transaction Cost Economics: The Natural Progression. Amer. Econ. Rev., 100(3), 673-690.

Yahaya, ML; Oyediran, OS; Onukuwbe, HN (2019a). Evaluating Factors Affecting Transaction Costs of Contractors in Public Procurement in Nigeria: PLSSEM Approach. FUTY J of the Env. 13(1), 46-64.

Yahaya, ML; Oyediran, OS; Onukwube, HN (2019b). Magnitude of Transaction Costs on Contractors for Eligibility Documents, Contract Administration and Bidding, ATBU J. of Environ. Technol. 12(1), 47-78. 